\title{
Article
}

\section{Chromium-rich vanadio-oxy-dravite from the Tzarevskoye uranium-vanadium deposit, Karelia, Russia: a second world-occurrence of $\mathrm{Al}-\mathrm{Cr}-\mathrm{V}$-oxy-tourmaline}

\author{
Ferdinando Bosi ${ }^{1 \star}$ (1), Alessandra Altieri ${ }^{1}$, Fernando Cámara ${ }^{2,3}$ (I) and Marco E. Ciriotti ${ }^{4,5}$ \\ ${ }^{1}$ Department of Earth Sciences, Sapienza University of Rome, Piazzale Aldo Moro 5, I-00185 Rome, Italy; ${ }^{2}$ Department of Earth Sciences “Ardito Desio", University \\ of Milan, via Luigi Mangiagalli 34, 20133 Milan, Italy; ${ }^{3}$ CrisDi, Interdepartmental Centre for the Research and Development of Crystallography, via Pietro Giuria 5, \\ I-10125, Turin, Italy; ${ }^{4}$ Associazione Micromineralogica Italiana, via San Pietro 55, I-10073 Devesi-Cirié, Italy; and ${ }^{5}$ Dipartimento di Scienze della Terra, Università di \\ Torino, via Tommaso Valperga Caluso 35, I-10125 Torino, Italy
}

\begin{abstract}
A green tourmaline sample from the Tzarevskoye uranium-vanadium deposit, close to the Srednyaya Padma deposit, Lake Onega, Karelia Republic, Russia, has been found to be the second world-occurrence of Cr-rich vanadio-oxy-dravite in addition to the Pereval marble quarry, Sludyanka crystalline complex, Lake Baikal, Russia, type-locality. From the crystal-structure refinement and chemical analysis, the following empirical formula is proposed: ${ }^{\mathrm{X}}\left(\mathrm{Na}_{0.96} \mathrm{~K}_{0.02} \square_{0.02}\right)_{\Sigma 1.00}{ }^{\mathrm{Y}}\left(\mathrm{V}_{1.34} \mathrm{Al}_{0.68} \mathrm{Mg}_{0.93} \mathrm{Cu}_{0.02}^{2+} \mathrm{Zn}_{0.01} \mathrm{Ti}_{0.01}\right)_{\Sigma 3.00}$ $\mathrm{Z}_{(}\left(\mathrm{Al}_{3.19} \mathrm{Cr}_{1.36} \mathrm{~V}_{0.03} \mathrm{Mg}_{1.42}\right)_{\Sigma 6.00}\left({ }^{\mathrm{T}} \mathrm{Si}_{6} \mathrm{O}_{18}\right)\left({ }^{\mathrm{B}} \mathrm{BO}_{3}\right)_{3}{ }^{\mathrm{V}}(\mathrm{OH})_{3}{ }^{\mathrm{W}}\left[\mathrm{O}_{0.60}(\mathrm{OH})_{0.23} \mathrm{~F}_{0.17}\right]_{\Sigma 1.00}$. Together with the data from the literature, a compositional overview of $\mathrm{Al}-\mathrm{V}-\mathrm{Cr}-\mathrm{Fe}^{3+}$-tourmalines is provided by using ${ }^{[6]} \mathrm{Al}-\mathrm{V}-\mathrm{Cr}-\mathrm{Fe}^{3+}$ diagrams for tourmaline classification. These diagrams further simplify the tourmaline nomenclature as they merge the chemical information over the octahedrally-coordinated sites $(Y$ and $Z$ ) by removing the issues of uncertainty associated with cation order-disorder across $Y$ and $Z$. Results show the direct identification of tourmalines by using the chemical data alone.
\end{abstract}

Keywords: tourmaline, crystal-structure refinement, electron microprobe, nomenclature

(Received 6 August 2020; accepted 1 October 2020; Accepted Manuscript published online: 23 October 2020; Associate Editor: Ian T. Graham)

\section{Introduction}

The tourmaline-supergroup minerals are chemically complex borosilicates. They are widespread in the Earth's crust, occurring in sedimentary rocks, granites and granitic pegmatites and in lowgrade to ultrahigh-pressure metamorphic rocks (e.g. Dutrow and Henry, 2011). In accordance with Henry et al. (2011), the general formula of tourmaline can be written as $\mathrm{XY}_{3} \mathrm{Z}_{6} \mathrm{~T}_{6} \mathrm{O}_{18}\left(\mathrm{BO}_{3}\right)_{3} \mathrm{~V}_{3} \mathrm{~W}$, where $\mathrm{X}=\mathrm{Na}^{+}, \mathrm{K}^{+}, \mathrm{Ca}^{2+}$ and $\square$ $\left(\square=\right.$ vacancy); $\mathrm{Y}=\mathrm{Al}^{3+}, \mathrm{Fe}^{3+}, \mathrm{Cr}^{3+}, \mathrm{V}^{3+}, \mathrm{Mg}^{2+}, \mathrm{Fe}^{2+}, \mathrm{Mn}^{2+}$ and $\mathrm{Li}^{+} ; \mathrm{Z}=\mathrm{Al}^{3+}, \mathrm{Fe}^{3+}, \mathrm{Cr}^{3+}, \mathrm{V}^{3+}, \mathrm{Mg}^{2+}$ and $\mathrm{Fe}^{2+} ; \mathrm{T}=\mathrm{Si}^{4+}, \mathrm{Al}^{3+}$ and $\mathrm{B}^{3+} ; \mathrm{B}=\mathrm{B}^{3+}, \mathrm{V}=\mathrm{OH}^{1-}$ and $\mathrm{O}^{2-}$ and $\mathrm{W}=\mathrm{OH}^{1-}, \mathrm{F}^{1-}$ and $\mathrm{O}^{2-}$. The (non-italicised) letters $\mathrm{X}, \mathrm{Y}, \mathrm{Z}, \mathrm{T}$ and $\mathrm{B}$ represent groups of cations accommodated at the ${ }^{[9]} X,{ }^{[6]} Y,{ }^{[6]} Z,{ }^{[4]} T$ and ${ }^{[3]} B$ crystallographic sites (identified with italicised letters); the letters $\mathrm{V}$ and $\mathrm{W}$ represent groups of anions accommodated at the ${ }^{[3]} \mathrm{O}(3)$ and ${ }^{[3]} \mathrm{O}(1)$ crystallographic sites, respectively. The $\mathrm{H}$ atoms occupy the $H(3)$ and $H(1)$ sites, which are related to $\mathrm{O}(3)$ and $\mathrm{O}(1)$, respectively (e.g. Bosi, 2013; Gatta et al., 2014).

\footnotetext{
${ }^{\star}$ Author for correspondence: Ferdinando Bosi, Email: ferdinando.bosi@uniromal.it Cite this article: Bosi F., Altieri A., Cámara F. and Ciriotti M.E. (2020) Chromium-rich vanadio-oxy-dravite from the Tzarevskoye uranium-vanadium deposit, Karelia, Russia: a second world-occurrence of Al-Cr-V-oxy-tourmaline. Mineralogical Magazine 84, 797-804. https://doi.org/10.1180/mgm.2020.77
}

Due to their highly variable chemical composition and refractory behaviour, tourmaline is considered a very useful indicator of geological processes in igneous, hydrothermal and metamorphosed systems (Dutrow and Henry, 2011; van Hinsberg et al., 2011; Ahmadi et al., 2019; Sipahi, 2019) and able to record and preserve the chemical composition of their host rocks.

Vanadium and Cr-bearing hydroxyl- and oxy-tourmaline species have been described widely in the literature (Cossa and Arzruni, 1883; Badalov, 1951; Bassett, 1953; Snetsinger, 1966; Peltola et al., 1968; Jan et al., 1972; Dunn, 1977; Nuber and Schmetzer, 1979; Foit and Rosenberg, 1979; Rumyantseva, 1983; Gorskaya et al., 1984, 1987; Reznitskii et al., 1988; Hammarstrom, 1989; Kazachenko et al., 1993; Reznitskii and Sklyarov, 1996; Ertl et al., 2008; Arif et al., 2010; Lupulescu and Rowe, 2011; Rozhdestvenskaya et al., 2011; Cempírek et al., 2013; Vereshchagin et al., 2014). Currently, they are known from several localities: Sludyanka (Slyudyanka) crystalline complex, Lake Baikal, Russia; Onega region, Central Karelia, Russia; Primorye, Far eastern Russia; Balmat, St. Lawrence County, New York, USA; Silver Knob deposit, Mariposa County, California, USA; Nausahi deposit, Orissa, India; Outokumpu deposit, Finnish North Karelia, Finland; Mingora and Gujar Kili mines, Swat, Pakistan; Alpurai, Pakistan; Shabrovskoe ore deposit, Middle Urals, Russia; Syssertox Dach, Ural Mountains, Russia; Umba Valley, Tanga Province, Tanzania; Kwal District, Kenya; 
Amstall, Lower Austria, Austria; and Bítovánky, Czech Republic. Also, fluor-rich tourmalines characterised by $\mathrm{V}$ and $\mathrm{Cr}$ have been reported in the literature with a strong positive relation between $\mathrm{F}$ and $\mathrm{Cr}$, but with $\mathrm{F}$ contents less than 0.5 atoms per formula unit (Bosi et al., 2017b).

Oxy-tourmalines rich in both $\mathrm{V}$ and $\mathrm{Cr}$ are unusual minerals and occur almost exclusively in metamorphosed V- and $\mathrm{Cr}$-enriched host rocks such as sulfide-rich black shales, graphite quartzites and calcareous metasediments (Snetsinger, 1966; Kazachenko et al., 1993; Bačik et al., 2011; Cempírek et al., 2013). Most oxy-tourmalines with dominant $\mathrm{V}$ and/or $\mathrm{Cr}$ $\left(\mathrm{V}_{2} \mathrm{O}_{3}\right.$ or $\mathrm{Cr}_{2} \mathrm{O}_{3}>9$ wt.\%) were found in the Sludyanka crystalline complex, Lake Baikal, Russia (Bosi et al., 2004, 2012, 2013a,b; Reznitskii et al., 2014; Bosi et al., 2014a,b, 2017a,b). Among these is a vanadio-oxy-dravite, ideally $\mathrm{NaV}_{3}\left(\mathrm{Al}_{4} \mathrm{Mg}_{2}\right)\left(\mathrm{Si}_{6} \mathrm{O}_{18}\right)$ $\left(\mathrm{BO}_{3}\right)_{3}(\mathrm{OH})_{3} \mathrm{O}$, a rare tourmaline recently described by Bosi et al. (2014a).

The sample studied was found in the Tzarevskoye uraniumvanadium deposit, close to the Srednyaya Padma deposit, Zaonezhye Peninsula, Lake Onega, Karelia Republic, Northern Region, Russia. It is the first occurrence of V-dominant, Cr-rich oxy-tourmaline in Karelia and the second world-occurrence in addition to the Pereval marble quarry (Sludyanka) type-locality. In this work, we describe this tourmaline and provide a compositional overview of $\mathrm{Al}-\mathrm{V}-\mathrm{Cr}-\mathrm{Fe}^{3+}$-tourmalines.

\section{Geological setting}

The Srednyaya Padma mine is the largest of the deposits from vanadium, uranium and precious metals of the Onega region and has abnormally high concentrations of gold, palladium, platinum, copper and molybdenum. It is concentrated in the Onega epicratonic trough, which is filled with volcano-sedimentary rocks of Lower Proterozoic age (organic carbon-rich schists, sandstones, dolomites and tuffites prevail) (Boitsov, 1997). The ore mineralisation is located in the albite-mica-carbonate metasomatites upon the Proterozoic aleorolites and schists (Boitsov, 1997). The distribution of these ore-bearing metasomatites is controlled by axial faults and shear zones. In fact the Srednyaya Padma deposit is located in zones of fold-fracture dislocations, which are represented by systems of $\mathrm{N}-\mathrm{W}$ oriented anticlines with interior portions of the anticlines composed of dolomites and exterior portions composed of schists. The orebodies are situated in steeply-dipping fracture zones in siltstones and in some wedge-shaped zones at the contact with the schungite schists.

The Srednyaya Padma deposit is $3 \mathrm{~km}$ long and consists of two orebodies with different amounts of $\mathrm{V}$ and $\mathrm{U}$ (Boitsov, 1997): the first orebody has a length of $1060 \mathrm{~m}$, thickness $40-50 \mathrm{~m}$, with an average $\mathrm{V}_{2} \mathrm{O}_{5}$ and $\mathrm{UO}_{2}$ content of $\sim 3 \mathrm{wt} . \%$ and $0.13 \mathrm{wt} . \%$, respectively, whereas the second has a length of $1840 \mathrm{~m}$, vertical size of $100-450 \mathrm{~m}$ and an average content of $\mathrm{V}_{2} \mathrm{O}_{5}$ and $\mathrm{UO}_{2}$ of $\sim 2.4$ wt.\% and 0.11 wt.\%, respectively.

In accordance with Borozdin et al. (2014), the main minerals of the ore metasomatites are $\mathrm{V}$ - and Cr-micas (roscoelite, chromceladonite and Cr-bearing micas of the phengite series), which make-up $\sim 26 \%$ of all ores, carbonate marbles (dolomite and calcite), with $\sim 21 \%$, feldspars (albite, which usually prevails over other minerals with a mean content of $\sim 37 \%$ ), minor $\mathrm{V}-\mathrm{Cr}$ alkaline pyroxenes (natalyite and Cr-bearing aegirine) and $\mathrm{Cr}$-rich tourmalines.
The tourmaline studied was found in the Tzarevskoye uranium-vanadium deposit, $\sim 14 \mathrm{~km}$ from the well-known Srednyaya Padma deposit. The Tzarevskoye deposit is situated in the anticline zone with cores of metamorphosed terrigenouscarbonate rocks in the cores and intensely brecciated, mylonitised and foliated metamorphosed siltstones at the margins of the folds. The tectonic activity was accompanied by hydrothermalmetasomatic and hypogene processes (Boitsov, 1997). The tourmaline sample occurs in micaceous metasomatites, associated with roscoelite, Cr-bearing phengite micas, quartz and dolomite. It forms dark-green to black pyramidal crystals up to $0.1 \mathrm{~mm}$. A similar mineralogical association was observed for the chromium-dravite from the Velikaya Guba gold-copper-uranium occurrence (see below).

\section{Experimental Methods}

\section{Electron-microprobe analysis}

Electron-microprobe analyses of the present sample were obtained by a wavelength-dispersive spectrometer (WDS mode) using a CAMECA SX50 instrument at the Istituto di Geologia Ambientale e Geoingegneria (CNR of Rome, Italy), operating at an accelerating potential of $15 \mathrm{kV}$ and a sample current of $15 \mathrm{nA}$, with a $10 \mu \mathrm{m}$ beam diameter. Minerals and synthetic compounds were used as standards as follows: wollastonite ( $\mathrm{Si}$ and $\mathrm{Ca})$, magnetite $(\mathrm{Fe})$, rutile $(\mathrm{Ti})$, corundum $(\mathrm{Al})$, karelianite $(\mathrm{V})$, fluorphlogopite $(\mathrm{F})$, periclase $(\mathrm{Mg})$, jadeite $(\mathrm{Na})$, orthoclase $(\mathrm{K})$, rhodonite $(\mathrm{Mn})$, metallic $\mathrm{Cr}, \mathrm{Ni}, \mathrm{Cu}$ and $\mathrm{Zn}$. Vanadium and $\mathrm{Cr}$ concentrations were corrected for interference from the TiK $\beta$ and VK $\beta$ peaks, respectively. The PAP matrix correction procedure (Pouchou and Pichoir 1991) was applied to reduce the raw data. The results, which are summarised in Table 1, represent mean values of 4 spot analyses. In accordance with Pesquera et al. (2016), the $\mathrm{Li}_{2} \mathrm{O}$ content was assumed to be insignificant as $\mathrm{MgO}>2 \mathrm{wt} . \%$ is contained in the sample studied. Calcium, $\mathrm{Mn}, \mathrm{Fe}$ and $\mathrm{Ni}$ were below the detection limits (0.03 wt.\%).

\section{Single-crystal structural refinement (SREF)}

A pale green crystal fragment $(0.037 \mathrm{~mm} \times 0.042 \mathrm{~mm} \times$ $0.052 \mathrm{~mm}$ ) of the sample was mounted on an Oxford Gemini $\mathrm{R}$ Ultra diffractometer equipped with a Ruby CCD area detector at CrisDi (Interdepartmental Centre for the Research and Development of Crystallography, Turin, Italy) with graphitemonochromatised $\mathrm{MoK} \alpha$ radiation from a fine-focus sealed $\mathrm{X}$-ray tube. The sample-to-detector distance was $5.3 \mathrm{~cm}$. A total of 222 exposures (step $=1^{\circ}$, time $/$ step $=48-478 \mathrm{~s}$ ) with an average redundancy of $\sim 6$ was used. Data were integrated and corrected for Lorentz and polarisation background effects, using CrysAlisPro (Agilent Technologies, Version 1.171.36.20, release 27-06-2012 CrysAlis171.36.24). Refinement of the unit-cell parameters was based on 2304 measured reflections. The data were corrected for absorption using the multi-scan method (Scale3 $A B S P A C K)$. No violations of $R 3 m$ symmetry were noted.

Structural refinement was done with the SHELXL-2013 program (Sheldrick, 2013). Starting coordinates were taken from Bosi et al. (2014a). Variable parameters were: scale factor, atomic coordinates, site scattering values and atomic-displacement factors. Attempts to refine the extinction coefficient yielded values within its standard uncertainty, thus it has not been refined. Neutral scattering factors were used for the cations and a fully 
Table 1. Chemical composition for Cr-rich vanadio-oxy-dravite from the Tzarevskoye deposit, Russia.

\begin{tabular}{lcll}
\hline & wt.\% & & apfu \\
\hline $\mathrm{SiO}_{2}$ & $34.58(39)$ & $\mathrm{Si}$ & 6.00 \\
$\mathrm{TiO}_{2}$ & $0.11(6)$ & $\mathrm{Ti}^{4+}$ & 0.01 \\
$\mathrm{~B}_{2} \mathrm{O}_{3}{ }^{*}$ & 10.02 & $\mathrm{~B}$ & 3.00 \\
$\mathrm{Al}_{2} \mathrm{O}_{3}$ & $18.89(56)$ & $\mathrm{Al}$ & 3.86 \\
$\mathrm{Cr}_{2} \mathrm{O}_{3}$ & $9.93(68)$ & $\mathrm{Cr}^{3+}$ & 1.36 \\
$\mathrm{~V}_{2} \mathrm{O}_{3}$ & $9.87(33)$ & $\mathrm{V}^{3+}$ & 1.37 \\
$\mathrm{MgO}$ & $9.10(64)$ & $\mathrm{Mg}$ & 2.35 \\
$\mathrm{CuO}$ & $0.18(13)$ & $\mathrm{Cu}$ & 0.02 \\
$\mathrm{ZnO}^{2+}$ & $\mathrm{Zn}$ & 0.01 \\
$\mathrm{Na}$ & $\mathrm{Na}$ & $\mathrm{K}$ & 0.96 \\
$\mathrm{~K}_{2} \mathrm{O}$ & $0.09(4)$ & $\mathrm{F}$ & 0.02 \\
$\mathrm{~F}$ & $2.85(5)$ & $\mathrm{OH}$ & 0.17 \\
$\mathrm{H}_{2} \mathrm{O}^{*}$ & $0.10(3)$ & & 3.23 \\
$\mathrm{Total}$ & $0.31(14)$ & & \\
\hline
\end{tabular}

Notes: Errors for oxides are standard deviations (in parentheses) of 4 spot analyses; apfu = atoms per formula unit.

${ }^{\star}$ Calculated by stoichiometry.

ionised scattering factor for the oxygen atoms. In detail, the occupancy of the $X$ site was modelled by using the Na scattering factor, the $Y$ site $\mathrm{Mg}$ and $\mathrm{V}$ scattering factors, and the $Z$ site using $\mathrm{Al}$ and Cr scattering factors. The $T$ and $B$ sites were modelled, respectively, with $\mathrm{Si}$ and $\mathrm{B}$ scattering factors and with a fixed occupancy of 1 , because refinement with unconstrained occupancies showed no significant deviations from this value. Three full-matrix refinement cycles with isotropic-displacement parameters for all atoms were followed by anisotropic cycles until convergence was attained. No significant correlations over a value of 0.7 between the parameters were observed at the end of refinement. Table 2 lists crystal data, data-collection information, and refinement details; Table 3 gives the fractional atomic coordinates, site occupancies and displacement parameters; Table 4 gives selected bond distances. The crystallographic information file has been deposited with the Principal Editor of Mineralogical Magazine and is available as Supplementary material (see below).

\section{Results}

\section{Determination of atomic fractions}

In agreement with the SREF results, the $B$ content was assumed to be stoichiometric in the sample studied $\left(\mathrm{B}^{3+}=3.00\right.$ atoms per formula unit, apfu). In fact, both the site-scattering results and the bond lengths of $B$ and $T$ are consistent with the $B$ site fully occupied by $\mathrm{B}^{3+}$ and no amount of $\mathrm{B}^{3+}$ at the $T$ site. The $(\mathrm{OH})$ content can then be calculated by charge balance with the assumption $(\mathrm{T}+\mathrm{Y}+\mathrm{Z})=15.00 \mathrm{apfu}$ and 31 anions. The atomic fractions were calculated on these assumptions (Table 1). The excellent match between the number of electrons per formula unit (epfu) derived from chemical and structural analysis supports this procedure: 268.90 and $267.95 \mathrm{epfu}$, respectively.

\section{Determination of site populations and mineral formula}

The anion site populations in the sample studied follow the general preference suggested for tourmaline (e.g. Henry et al., 2011): the $\mathrm{O}(3)$ site (V position in the general formula) is occupied by $(\mathrm{OH})$, while the $\mathrm{O}(1)$ site (W position in the general formula) can be occupied by $\mathrm{O}^{2-},(\mathrm{OH})$ and $\mathrm{F}^{-}$. The $T$ site is fully occupied by $\mathrm{Si}$. The cation distribution at the $Y$ and $Z$ sites can be
Table 2. Single-crystal X-ray diffraction data: details for Cr-rich vanadio-oxy-dravite from the Tzarevskoye deposit, Russia.

\begin{tabular}{|c|c|}
\hline \multicolumn{2}{|l|}{ Crystal data } \\
\hline Crystal size (mm) & $0.037 \times 0.042 \times 0.052$ \\
\hline Space group & $R 3 m$ \\
\hline$a(\AA)$ & $16.0067(8)$ \\
\hline$c(\AA)$ & $7.3197(5)$ \\
\hline$V\left(\AA^{3}\right)$ & $1624.2(2)$ \\
\hline Density $\left(\mathrm{g} / \mathrm{cm}^{3}\right)$ & 3.146 \\
\hline Z & 3 \\
\hline Range for data collection, $\theta\left(^{\circ}\right)$ & 4-31.6 \\
\hline \multirow[t]{3}{*}{ Reciprocal space range $h k l$} & $-23 \leq h \leq 24$ \\
\hline & $-22 \leq k \leq 22$ \\
\hline & $-9 \leq l \leq 10$ \\
\hline \multicolumn{2}{|l|}{ Data collection } \\
\hline Radiation & MoK $\alpha=0.71073 \AA$ \\
\hline Data collection temperature (K) & 293 \\
\hline Total number of frames & 1235 \\
\hline Set of measured reflections & 3786 \\
\hline Unique reflections, $R_{\text {int }}(\%)$ & $1197,3.04$ \\
\hline Absorption correction method & multi-scan SCALE3 ABSPACK \\
\hline \multicolumn{2}{|l|}{ Refinement } \\
\hline Refinement method & Full-matrix last-squares on $F^{2}$ \\
\hline Structural refinement program & SHELXL-2013 \\
\hline Flack parameter & $0.07(6)$ \\
\hline$w R_{2}(\%)$ & 4.86 \\
\hline$R_{1}(\%)$ all data & 2.65 \\
\hline$R_{1}(\%)$ for $\mathrm{I}>2 \sigma(\mathrm{I})$ & 2.44 \\
\hline GoF & 1.088 \\
\hline$\Delta \rho_{\max }, \Delta \rho_{\min }\left( \pm e^{-} / \AA^{3}\right)$ & 0.45 and -0.35 \\
\hline
\end{tabular}

Notes: $R_{\text {int }}=$ merging residual value; $R_{1}=$ discrepancy index, calculated from $F$-data; $\mathrm{w} R_{2}=$ weighted discrepancy index, calculated from $F^{2}$-data; GoF = goodness of fit; $\Delta \rho_{\max }$, $\Delta \rho_{\min }=$ maximum and minimum residual electron density.

optimised according the procedure of Bosi et al. (2017b) and the ionic radii of Bosi (2018). In detail, the site distribution of $\mathrm{Mg}, \mathrm{Al}, \mathrm{V}^{3+}$ and $\mathrm{Cr}^{3+}$ was obtained by minimising the residuals between calculated and observed structural data (such as mean bond distance, site scattering expressed in terms of mean atomic number) by using a least-square approach. The minor amounts of $\mathrm{Ti}, \mathrm{Cu}^{2+}$ and $\mathrm{Zn}$ were assumed fixed at the $Y$ site. The resulting empirical crystal-chemical formula is

$$
\begin{aligned}
& \mathrm{X}\left(\mathrm{Na}_{0.96} \mathrm{~K}_{0.02} \square_{0.02}\right)_{\Sigma 1.00}{ }^{\mathrm{Y}}\left(\mathrm{V}_{1.34} \mathrm{Al}_{0.68} \mathrm{Mg}_{0.93} \mathrm{Cu}_{0.02}^{2+} \mathrm{Zn}_{0.01} \mathrm{Ti}_{0.01}\right)_{\Sigma 3.00} \\
& { }^{\mathrm{Z}}\left(\mathrm{Al}_{3.19} \mathrm{Cr}_{1.36} \mathrm{~V}_{0.03} \mathrm{Mg}_{1.42}\right)_{\Sigma 6.00}\left({ }^{\mathrm{T}} \mathrm{Si}_{6} \mathrm{O}_{18}\right)\left({ }^{\mathrm{B}} \mathrm{BO}_{3}\right)_{3}{ }^{\mathrm{V}}(\mathrm{OH})_{3} \\
& { }^{\mathrm{W}}\left[\mathrm{O}_{0.60}(\mathrm{OH})_{0.23} \mathrm{~F}_{0.17}\right]_{\Sigma 1.00}
\end{aligned}
$$

The observed mean atomic number and mean bond length values and those calculated from the optimised site-populations are in excellent agreement (Table 5). This cation distribution is consistent with the studies of Bosi et al. (2017b) and Bosi (2018), which showed that the preference of $\mathrm{Al}^{3+}, \mathrm{V}^{3+}$ and $\mathrm{Cr}^{3+}$ for the $Y$ and $Z$ sites is controlled mainly by the cation size according to the sequence: ${ }^{Y} \mathrm{~V}^{3+}>{ }^{Y} \mathrm{Cr}^{3+}>{ }^{Y} \mathrm{Al}^{3+}$ and ${ }^{Z} \mathrm{Al}^{3+}>{ }^{Z} \mathrm{Cr}^{3+}>{ }^{Z} \mathrm{~V}^{3+}$. Because $\langle Y-\mathrm{O}\rangle$ is always greater than $\langle Z-\mathrm{O}\rangle$ in tourmaline, the $Y$ site will in fact tend to incorporate relatively large cations, whereas the $Z$ site will tend to incorporate relatively small cations. This trend is documented by the preference of $\mathrm{V}^{3+}$ over $\mathrm{Cr}^{3+}$ to dominate the $Y$ site in the vanadio-oxy-chromium-dravite compositions. Compared to $\mathrm{Al}^{3+}, \mathrm{V}^{3+}$ prefers the $Y$ site (and $\mathrm{Al}^{3+}$ the $Z$ site) as observed in the vanadio-oxy-dravite samples.

The optimised empirical formula can be recast in its ordered form for classification purposes (Henry et al., 2011) by ordering 
Table 3. Displacement parameters $\left(\AA^{2}\right)$, fractional atom coordinates and site occupancy for Cr-rich vanadio-oxy-dravite from the Tzarevskoye deposit, Russia.

\begin{tabular}{|c|c|c|c|c|c|c|c|c|c|c|c|}
\hline Site & $x$ & $y$ & $z$ & Site occupancy & $U^{11}$ & $U^{22}$ & $U^{33}$ & $U^{23}$ & $U^{13}$ & $U^{12}$ & $U_{\text {eq }} / U_{\text {iso }}{ }^{*}$ \\
\hline Y & $0.12496(7)$ & $0.06248(3)$ & $0.63704(19)$ & $\mathrm{V}_{0.477(11)} \mathrm{Mg}_{0.523(11)}$ & $0.0066(5)$ & $0.0058(4)$ & $0.0108(6)$ & $-0.00061(18)$ & $-0.0012(4)$ & $0.0033(2)$ & $0.0077(3)$ \\
\hline$B$ & $0.10931(18)$ & $0.2186(4)$ & $0.4562(7)$ & $B_{1.00}$ & $0.0052(13)$ & $0.0084(18)$ & $0.0032(19)$ & $0.0017(15)$ & $0.0008(8)$ & $0.0042(9)$ & $0.0052(8)$ \\
\hline$T$ & $0.19098(5)$ & $0.18920(5)$ & 0 & $\mathrm{Si}_{1.00}$ & $0.0040(4)$ & $0.0039(3)$ & $0.0067(4)$ & $-0.0004(3)$ & $-0.0002(3)$ & $0.0021(3)$ & $0.00482(18)$ \\
\hline$O(1)(\equiv W)$ & 0 & 0 & $0.7674(8)$ & $\mathrm{O}_{1.00}$ & $0.0084(14)$ & $0.0084(14)$ & $0.011(3)$ & 0 & 0 & $0.0042(7)$ & $0.0091(10)$ \\
\hline $\mathrm{O}(2)$ & $0.06099(10)$ & $0.1220(2)$ & $0.4903(5)$ & $\mathrm{O}_{1.00}$ & $0.0085(10)$ & $0.0042(13)$ & $0.0103(16)$ & $0.0005(11)$ & $0.0003(6)$ & $0.0021(6)$ & $0.0081(6)$ \\
\hline $\mathrm{O}(5)$ & $0.1834(2)$ & $0.09170(12)$ & $0.0894(4)$ & $\mathrm{O}_{1.00}$ & $0.0166(16)$ & $0.0065(9)$ & $0.0092(15)$ & $0.0010(6)$ & $0.0021(12)$ & $0.0083(8)$ & $0.0096(6)$ \\
\hline $\mathrm{O}(6)$ & 0.19390(15) & $0.18413(15)$ & $0.7811(3)$ & $\mathrm{O}_{1.00}$ & $0.0092(10)$ & $0.0076(9)$ & $0.0061(10)$ & $-0.0002(8)$ & $0.0002(8)$ & $0.0042(8)$ & $0.0077(4)$ \\
\hline $\mathrm{O}(7)$ & $0.28347(14)$ & $0.28367(14)$ & $0.0766(3)$ & $\mathrm{O}_{1.00}$ & $0.0061(9)$ & $0.0058(9)$ & $0.0105(11)$ & $-0.0005(8)$ & $-0.0014(8)$ & $0.0004(8)$ & $0.0086(4)$ \\
\hline $\mathrm{O}(8)$ & $0.20718(15)$ & $0.26813(16)$ & $0.4406(3)$ & $\mathrm{O}_{1.00}$ & $0.0053(9)$ & $0.0099(10)$ & $0.0178(12)$ & $0.0033(9)$ & $0.0022(9)$ & $0.0041(8)$ & $0.0109(5)$ \\
\hline$H(3)$ & $0.260(4)$ & $0.1299(18)$ & $0.384(8)$ & $\mathrm{H}_{1.00}$ & & & & & & & $0.014^{\star}$ \\
\hline
\end{tabular}

${ }^{\star}$ Equivalent $\left(U_{\text {eq }}\right)$ and isotropic $\left(U_{\text {iso }}\right)$ displacement parameters; $\mathrm{H}$-atom was constrained to have a $U_{\text {iso }} 1.2$ times the $U_{\text {eq }}$ value of the $\mathrm{O}(3)$ oxygen.

Table 4. Selected bond distances $(\AA)$ for Cr-rich vanadio-oxy-dravite from the Tzarevskoye deposit, Russia.

\begin{tabular}{llll}
\hline$B-\mathrm{O}(8)^{\mathrm{a}} \times 2$ & $1.362(3)$ & $Y-\mathrm{O}(1)$ & $1.978(3)$ \\
$B-\mathrm{O}(2)^{\mathrm{a}}$ & $1.363(6)$ & $Y-\mathrm{O}(6)^{\mathrm{b}} \times 2$ & $1.993(2)$ \\
$<B-\mathrm{O}>$ & 1.362 & $Y-\mathrm{O}(2)^{\mathrm{c}} \times 2$ & $2.021(2)$ \\
& & $Y-\mathrm{O}(3)$ & $2.083(3)$ \\
$T-\mathrm{O}(7)$ & $1.598(2)$ & $<-\mathrm{O}>$ & 2.015 \\
$T^{\star}-\mathrm{O}(6)$ & $1.606(3)$ & & \\
$T-\mathrm{O}(4)$ & $1.6252(13)$ & $Z-\mathrm{O}(8)^{\mathrm{e}}$ & $1.933(2)$ \\
$T-\mathrm{O}(5)$ & $1.6399(15)$ & $Z-\mathrm{O}(7)^{\mathrm{e}}$ & $1.944(2)$ \\
$<T-\mathrm{O}>$ & 1.617 & $Z-\mathrm{O}(6)$ & $1.948(2)$ \\
& & $Z-\mathrm{O}(8)$ & $1.964(2)$ \\
$X-\mathrm{O}(2)^{\mathrm{b}, \mathrm{f}} \times 3$ & $2.512(4)$ & $Z-\mathrm{O}(7)^{\mathrm{d}}$ & $1.981(2)$ \\
$X-\mathrm{O}(5)^{\mathrm{b}, \mathrm{f}} \times 3$ & $2.761(4)$ & $Z-\mathrm{O}(3)$ & $2.0178(16)$ \\
$X-\mathrm{O}(4)^{\mathrm{b}, \mathrm{f}} \times 3$ & $2.845(4)$ & $<Z-\mathrm{O}>$ & 1.965 \\
$<X-\mathrm{O}>$ & 2.706 & $\mathrm{O}(3)-H(3)$ & $0.93(6)$ \\
\hline
\end{tabular}

Notes: Standard uncertainty in parentheses. Symmetry codes: $\mathrm{a}=(y-x, y, z) ; \mathrm{b}=(y-x,-x$, $z) ; \mathrm{c}=(x, x-y, z) ; \mathrm{d}=(y-x+1 / 3,-x+2 / 3, z+2 / 3) ; \mathrm{e}=(-y+2 / 3, x-y+1 / 3, z+1 / 3) ;$ and $\mathrm{f}=(-y, x-y, z)$. Transformations relate coordinates to those of Table 2 .

${ }^{\star}$ Positioned in adjacent unit cell.

all trivalent cations at the $Z$ site up to 6.00 apfu, according to the site preference $\mathrm{Al}>\mathrm{Cr}>\mathrm{V}>\mathrm{Fe}^{3+}$ (Bosi, 2018), and assigning any excess to $Y$ along with the other cations:

$$
\begin{aligned}
& \mathrm{X}\left(\mathrm{Na}_{0.96} \mathrm{~K}_{0.02} \square_{0.02}\right)_{\Sigma 1.00}{ }^{\mathrm{Y}}\left(\mathrm{Mg}_{2.05} \mathrm{~V}_{0.61} \mathrm{Cu}_{0.02}^{2+} \mathrm{Zn}_{0.01} \mathrm{Ti}_{0.01}\right)_{\Sigma 3.00} \\
& { }_{(}\left(\mathrm{Al}_{3.86} \mathrm{Cr}_{1.38} \mathrm{~V}_{0.76}\right)_{\Sigma 6.00}\left({ }^{\mathrm{T}} \mathrm{Si}_{6} \mathrm{O}_{18}\right)\left({ }^{\mathrm{B}} \mathrm{BO}_{3}\right)_{3}^{\mathrm{V}}(\mathrm{OH})_{3} \\
& { }^{\mathrm{W}}\left[\mathrm{O}_{0.60}(\mathrm{OH})_{0.23} \mathrm{~F}_{0.17}\right]_{\Sigma 1.00}
\end{aligned}
$$

Both the empirical and ordered formulae are consistent with an oxy-tourmaline species belonging to the alkali group, subgroup 3 (Henry et al., 2011): Na-dominant at the $\mathrm{X}$ position of the tourmaline general formula and oxygen-dominant at the $\mathrm{W}$ position with $\mathrm{O}^{2-}>(\mathrm{OH}+\mathrm{F})^{-}$. As $\mathrm{V}^{3+}$ is the dominant cation at $\mathrm{Y}$ and $\mathrm{Al}^{3+}$ is the dominant cation at $\mathrm{Z}$ along with relatively minor amounts of $\mathrm{Mg}$ required for formula electroneutrality (valency-imposed double-site occupancy; Bosi et al., 2019a), its endmember composition is $\mathrm{NaV}_{3}\left(\mathrm{Al}_{4} \mathrm{Mg}_{2}\right) \mathrm{Si}_{6} \mathrm{O}_{18}\left(\mathrm{BO}_{3}\right)_{3}(\mathrm{OH})_{3} \mathrm{O}$. As a result, the sample studied can be classified as Cr-rich vanadio-oxy-dravite.
Table 5. Optimised cation site populations (apfu), mean atomic numbers and

\begin{tabular}{|c|c|c|c|c|c|}
\hline \multirow[b]{2}{*}{ Site } & \multirow[b]{2}{*}{ Site population } & \multicolumn{2}{|c|}{ Mean atomic number } & \multicolumn{2}{|c|}{ Mean bond length } \\
\hline & & observed & calculated & observed & calculated $^{\star}$ \\
\hline$x$ & $0.96 \mathrm{Na}+0.02 \mathrm{~K}+0.02 \square$ & $10.84(18)$ & 10.93 & & \\
\hline Y & $\begin{array}{l}1.34 \mathrm{~V}^{3+}+0.68 \mathrm{Al}+0.93 \\
\quad \mathrm{Mg}+0.02 \mathrm{Cu}^{2+}+0.01 \mathrm{Ti}^{4+} \\
\quad+0.01 \mathrm{Zn}\end{array}$ & $17.25(19)$ & 17.41 & 2.015 & 2.013 \\
\hline$Z$ & $\begin{array}{l}3.19 \mathrm{Al}+1.36 \mathrm{Cr}^{3+}+0.03 \mathrm{~V}^{3+} \\
\quad+1.42 \mathrm{Mg}\end{array}$ & $15.22(9)$ & 15.31 & 1.965 & 1.962 \\
\hline$T$ & $6 \mathrm{Si}$ & $14^{\star \star}$ & 14 & & \\
\hline$B$ & $3 \mathrm{~B}$ & $5^{\star \star}$ & 5 & & \\
\hline
\end{tabular}
mean bond lengths ( $\AA$ ) for Cr-rich vanadio-oxy-dravite from the Tzarevskoye deposit, Russia.

Note: apfu = atoms per formula unit.

${ }^{\star}$ Calculated from empirical ionic radii (in $\AA$ ) of Bosi (2018): $\mathrm{Al}=0.547, \mathrm{Fe}^{3+}=0.675, \mathrm{Fe}^{2+}=$ $0.776, \mathrm{Mn}^{2+}=0.809, \mathrm{Zn}=0.740, \mathrm{Li}=0.751$ and $\mathrm{Ti}=0.605$; the mean $\mathrm{Y}$ and $\mathrm{Z}$ anion radii are functions of constituent-anion radius ( 1.360 and 1.357 , respectively).

${ }^{\star \star}$ Fixed in the final stages of refinement

\section{Discussion}

Similar to other tourmalines from the Sludyanka crystalline complex (Lake Baikal), the vanadio-oxy-dravite sample studied is also strongly enriched in Cr. Karelia appears to be an important area of the world in hosting tourmalines highly enriched in both $\mathrm{Cr}$ and V. In particular, the first description of chromium-dravite, ideally $\mathrm{NaMg}_{3} \mathrm{Cr}_{6}\left(\mathrm{Si}_{6} \mathrm{O}_{18}\right)\left(\mathrm{BO}_{3}\right)_{3}(\mathrm{OH})_{3} \mathrm{OH}$ is from Karelia (Rumyantseva, 1983). More precisely, the holotype chromiumdravite specimen occurs in micaceous metasomatic clay-carbonate rocks from the Velikaya Guba gold-copper-uranium occurrence, Zaonezhye peninsula, Lake Onega, Karelia Republic, Northern Region, Russia. The Velikaya Guba occurrence is close to $(\sim 18 \mathrm{~km})$ the Tzarevskoye deposit where the sample studied was found. The empirical formula of chromium-dravite (Rumyantseva, 1983) recast in its ordered form is as follows:

$$
\begin{gathered}
\mathrm{X}\left(\mathrm{Na}_{0.97} \mathrm{Ca}_{0.03}\right)_{\Sigma 1.00}{ }^{\mathrm{Y}}\left(\mathrm{Mg}_{2.57} \mathrm{~V}_{0.22} \mathrm{Fe}_{0.16}^{3+} \mathrm{Mn}_{0.03} \mathrm{Ti}_{0.02}\right)_{\Sigma 3.00} \\
\left.{ }^{\mathrm{Z}}\left(\mathrm{Cr}_{4.71} \mathrm{Fe}_{0.92}^{3+} \mathrm{Al}_{0.37}\right)_{\Sigma 6.00}\left[{ }^{\mathrm{T}}\left(\mathrm{Si}_{5.81} \mathrm{Al}_{0.19}\right)_{\Sigma 6.00} \mathrm{O}_{18}\right)\right] \\
{\left[{ }^{\mathrm{B}}\left(\mathrm{B}_{0.97} \mathrm{Al}_{0.03}\right)_{\Sigma 1.00} \mathrm{O}_{3}\right]_{3}(\mathrm{OH})_{3}\left[(\mathrm{OH})_{0.77} \mathrm{O}_{0.23}\right]_{\Sigma 1.00} .}
\end{gathered}
$$

From a classification viewpoint (Henry et al., 2011), this formula corresponds to a $\mathrm{Fe}^{3+}$-rich, $\mathrm{V}$-bearing chromium-dravite 


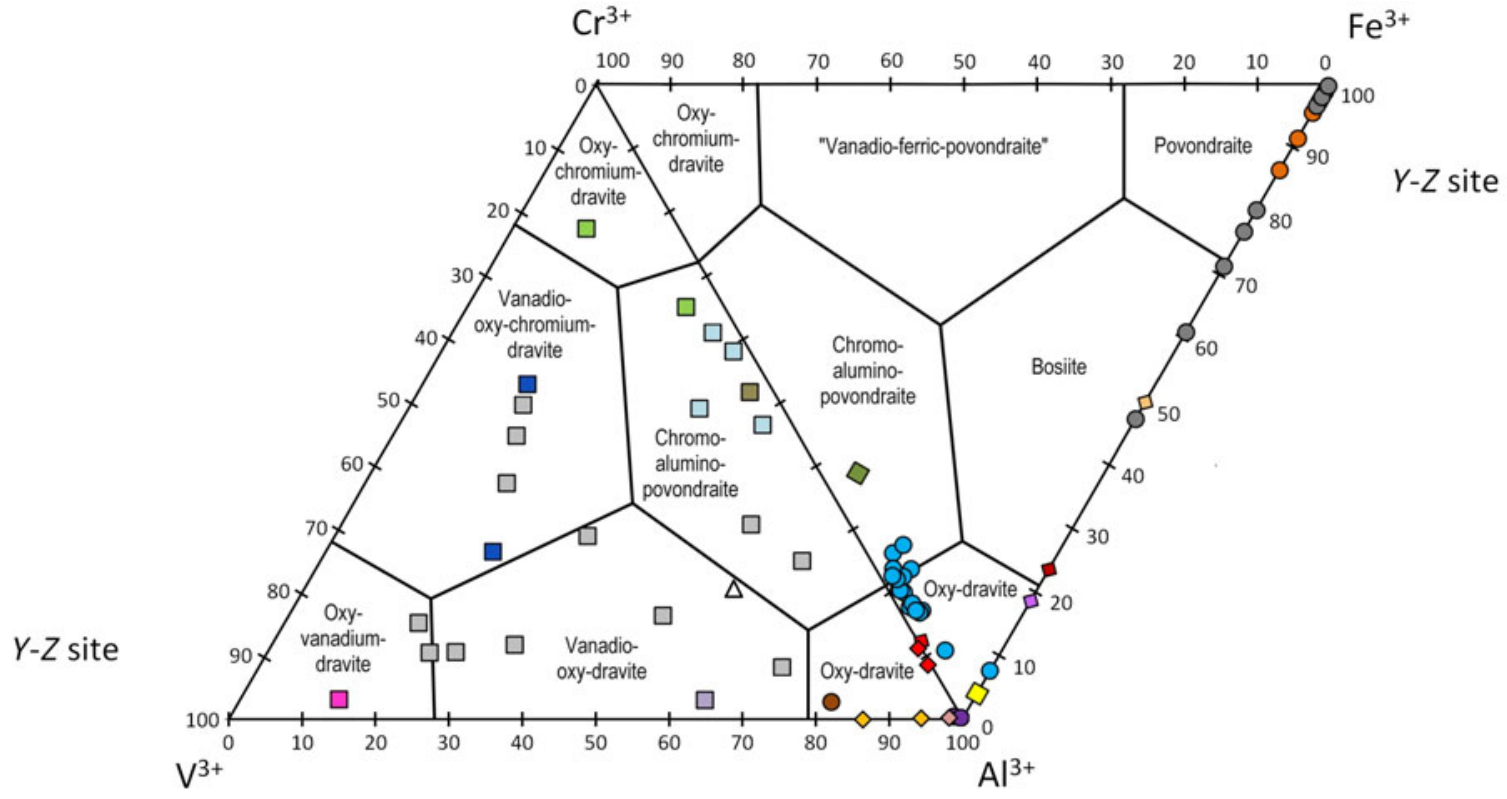

\begin{tabular}{|c|c|}
\hline$\Delta$ This work (Tzarevskoye deposit, Karelia, Lake Onega, Russia) & - Grice et al. (1993) (San Francisco mine, Bolivia) \\
\hline -Foit and Rosenberg (1979) (Silver Knob, Mariposa County, Californi & • Żàĉek et al. (2000) (Alto Chapare, Cochabamba, Bolivia) \\
\hline • Ertl et al. (2008) (Tanzania) & - Arif et al. (2010) (Swat, Pakistan) \\
\hline${ }^{\diamond}$ Ertl et al. (2008) (Amstall, Lower Austria) & - Bosi et al. (2017b) (Valletta mine, Italy) \\
\hline${ }^{\diamond}$ Cempírek et al. (2013) (Bítovánky, Czech Republic) & - Baksheev et al. (2011) (Darasun deposit, Transbaikalia, Russia) \\
\hline - Vereshchagin et al. (2014) (Middle Urals, Russia) & $\diamond$ Ertl et al. (2016) (Darsun deposit, Transbaikalia, Russia) \\
\hline${ }$ Bosi et al. (2004) (Sludyanka, Lake Baikal, Russia) & - Vereshchagin et al. (2014) (Middle Urals, Russia) \\
\hline Bosi et al. (2012) (Sludyanka, Lake Baikal, Russia) & - Bosi et al. (2013a) (Sludyanka, Lake Baikal, Russia) \\
\hline Bosi et al. (2013a) (Sludyanka, Lake Baikal, Russia) & $\square$ Bosi et al. (2013b) (Sludyanka, Lake Baikal, Russia) \\
\hline
\end{tabular}

口osi et al. (2014a) (Sludyanka, Lake Baikal, Russia)

-Bosi et al. (2014b) (Sludyanka, Lake Baikal, Russia)

"Reznitskii et al. (2014) (Sludyanka, Lake Baikal, Russia)

${ }^{\square}$ Bosi et al. (2017a) (Sludyanka, Lake Baikal, Russia)

Fig. 1. Plot of oxy-tourmaline compositions on the ${ }^{[6]} \mathrm{Al}-\mathrm{V}-\mathrm{Cr}-\mathrm{Fe}^{3+}$ diagram, obtained using 69 data sets.

(hydroxy-species) belonging to alkali subgroup 1. Compared to the sample studied, significant chemical differences at the octahedrally coordinated sites can be noted between the tourmalines from Karelia: the studied oxy-species $\left({ }^{\mathrm{W}} \mathrm{O}=0.60 \mathrm{apfu}\right)$ has $\mathrm{Mg}=2.05 \mathrm{apfu}, \mathrm{Al}=3.86 \mathrm{apfu}, \mathrm{V}=1.37 \mathrm{apfu}$ and $\mathrm{Cr}=1.38 \mathrm{apfu}$, whereas the chromium-dravite hydroxy-species $\left({ }^{\mathrm{W}} \mathrm{OH}=\right.$ $0.77 \mathrm{apfu})$ has $\mathrm{Mg}=2.57 \mathrm{apfu}, \mathrm{Al}=0.37 \mathrm{apfu}, \mathrm{V}=0.22 \mathrm{apfu}$, $\mathrm{Cr}=4.71 \mathrm{apfu}$ and $\mathrm{Fe}^{3+}=1.18$ apfu. These differences lead to the following $(\mathrm{Y}+\mathrm{Z})$ charge arrangements following Bosi et al. (2019b), ${ }^{\mathrm{Y}+\mathrm{Z}}\left(\mathrm{R}_{2}^{2+} \mathrm{R}_{7}^{3+}\right)$ for the oxy-species and ${ }^{\mathrm{Y}+\mathrm{Z}}\left(\mathrm{R}_{3}^{2+} \mathrm{R}_{6}^{3+}\right)$ for the hydroxy-species, which should be reflected in two different compositional diagrams for their classification. Recently, Henry and Dutrow (2018) proposed two ternary diagrams for the ${ }^{[6]} \mathrm{Al}-\mathrm{V}-\mathrm{Cr}$ subsystem and ${ }^{[6]} \mathrm{Al}-\mathrm{Cr}-\mathrm{Fe}^{3+}$ subsystem of the ${ }^{[6]} \mathrm{Al}-\mathrm{V}-\mathrm{Cr}-\mathrm{Fe}^{3+}$ quaternary system to classify oxy-tourmalines $\left({ }^{\mathrm{W}} \mathrm{O}^{2-}>0.5 \mathrm{apfu}\right)$. It is worth noting that this diagram includes trivalent cations at both the $Y$ and $Z$ sites to remove issues of uncertainty associated with order-disorder across these sites.

In order to better show the chemical variability of oxytourmalines in the ${ }^{[6]} \mathrm{Al}-\mathrm{V}-\mathrm{Cr}-\mathrm{Fe}^{3+}$ quaternary system, we have merged the diagrams ${ }^{[6]} \mathrm{Al}-\mathrm{Cr}-\mathrm{V}$ and ${ }^{[6]} \mathrm{Al}-\mathrm{Cr}-\mathrm{Fe}^{3+}$ through the edge ${ }^{[6]} \mathrm{Al}-\mathrm{Cr}$ (Fig. 1). We made these ternaries because no tourmaline rich in both $\mathrm{V}$ and $\mathrm{Fe}^{3+}$ has been found so far.
With regard to the classification of hydroxy/fluor-tourmalines $(\mathrm{OH}+\mathrm{F}>0.5 \mathrm{apfu}$ at $\mathrm{W})$, the ternary diagram for the $\mathrm{Al}-\mathrm{Fe}^{3+}-$ $\mathrm{Cr}$ subsystem (Fig. 2) of the $\mathrm{Al}-\mathrm{V}-\mathrm{Cr}-\mathrm{Fe}^{3+}$ quaternary system is used (Henry et al., 2011). This diagram is based on occupancy of the $Z$ site obtained from the tourmaline ordered formula, which also removes issues of uncertainty associated with orderdisorder across the $Y$ and $Z$ sites as may occur for example between $\mathrm{Fe}^{2+}-\mathrm{Al}$ in schorl (Andreozzi et al., 2020). In other words, the use of the diagrams in Figs 1 and 2 is equivalent to classifying tourmalines using only the chemical information of the $Y$ and $Z$ sites.

The plotted data in these diagrams (for a total 109 data sets) are from: Peltola et al. (1968); Foit and Rosenberg (1979); Nuber and Schmetzer (1979); Rumyantseva (1983); Gorskaya et al. (1987, 1989); Cavarretta and Puxeddu (1990); Grice et al. (1993); Grice and Ercit (1993); Ż̀âek et al. 2000; Bosi et al. (2004, 2012, 2013a,b, 2014a,b, 2017a,b); Ertl et al. (2008, 2016); Arif et al. (2010), in which Fe was considered +3 as suggested by the authors; Baksheev et al. (2011); Lupulescu and Rowe (2011); Rozhdestvenskaya et al. (2011); Cempírek et al. (2013); Reznitskii et al. (2014) and Vereshchagin et al. (2014).

The position of Cr-rich vanadio-oxy-dravite from the Tzarevskoye uranium-vanadium deposit close to the chromo-alumino-povondraite boundary is shown in Fig. 1. 


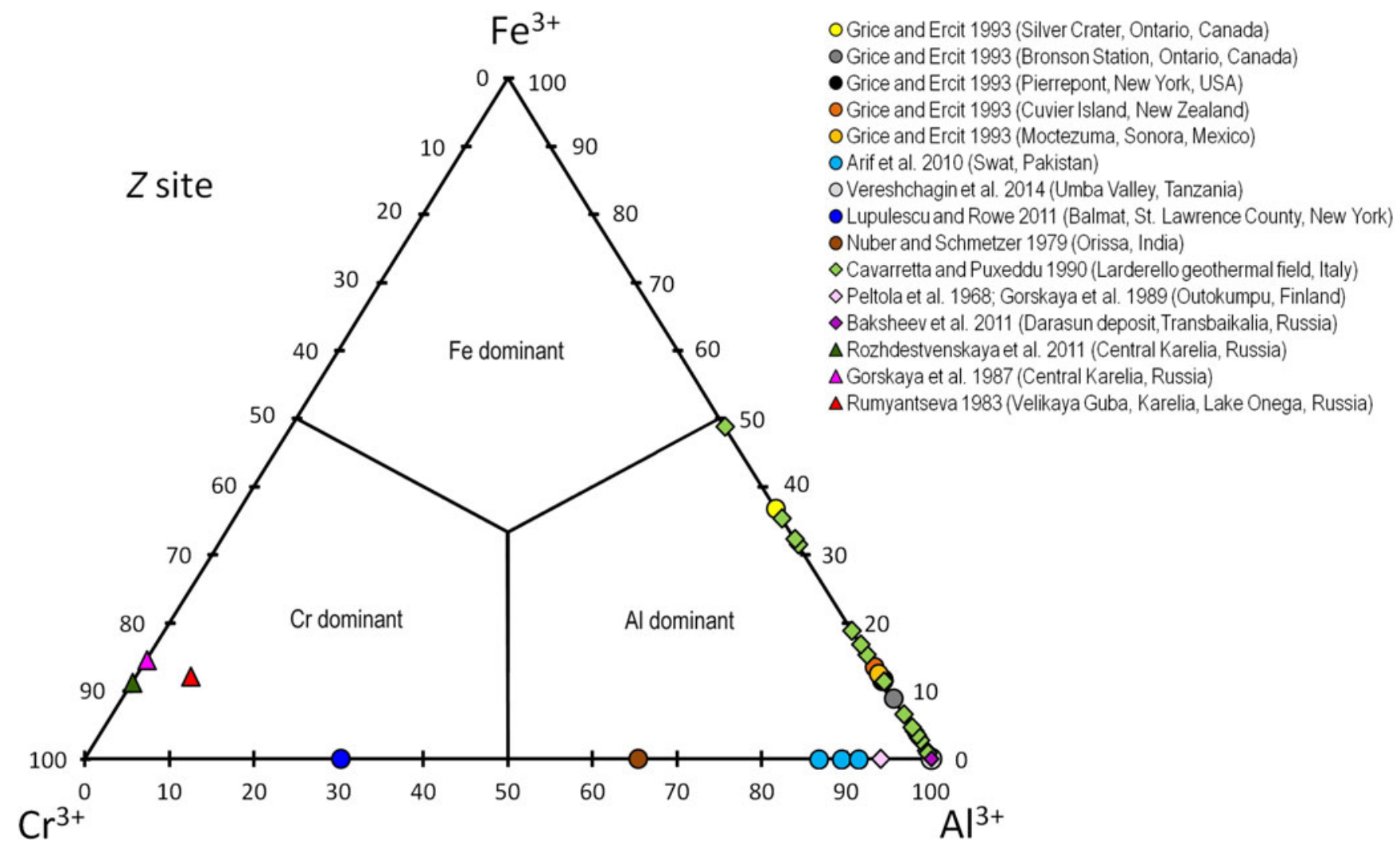

Fig. 2. Plot of hydroxy-tourmaline compositions on the ${ }^{[6]} \mathrm{Al}-\mathrm{Cr}-\mathrm{Fe}^{3+}$ diagram, obtained using 33 data sets.

Moreover, the complete chemical variability of the ${ }^{[6]} \mathrm{Al}-\mathrm{Cr}-\mathrm{V}$ oxy-tourmalines can be compared to the only chemical variability of $\mathrm{Fe}^{3+}$ occurring along the oxy-dravite-bosiite-povondraite series. From a nomenclature viewpoint, the range of the oxytourmaline compositions is valid for most of the oxy-tourmalines classified by considering the actual cation distributions over the $Y$ and $Z$ sites as overriding information for the definition of a tourmaline species (Henry et al., 2013). The only exception regards one of the two samples described by Bosi et al. (2012) as oxy-chromium-dravite, which falls in the chromo-aluminopovondraite field. Also note that the V-bearing tourmaline from Silver Knob, California, USA (Foit and Rosenberg, 1979) is classified as V-rich oxy-dravite (Fig. 1).

The position of the chromium-dravite from the Velikaya Guba gold-copper-uranium occurrence (Rumyantseva, 1983) with respect to the other $\mathrm{Cr}-\mathrm{Fe}^{3+}$ hydroxy-tourmalines from the literature is shown in Fig. 2. This figure shows the occurrence of a complete chemical variability along the dravite-chromium-dravite series and a partial variability from dravite to the hypothetical end-member $\mathrm{NaMg}_{3} \mathrm{Fe}_{6}^{3+}\left(\mathrm{Si}_{6} \mathrm{O}_{18}\right)\left(\mathrm{BO}_{3}\right)_{3}(\mathrm{OH})_{3} \mathrm{OH}$ of the samples from Larderello geothermal field, Italy (Cavarretta and Puxeddu, 1990). However, it should be noted that in all the oxy- and hydroxy-tourmalines plotted in Figs 1 and 2 the oxidation state of $\mathrm{Fe}$ has always been assumed to be +3 by the various authors, except for the Fe-bearing chromo-aluminopovondraite from the Sludyanka crystalline complex, Russia (Bosi et al., 2013b). The latter was characterised by Mössbauer spectroscopy resulting in $\mathrm{Fe}_{2} \mathrm{O}_{3}=2.49$ wt.\% and $\mathrm{FeO}=1.05$ wt.\%. To date, this is the only experimental information confirming the presence of $\mathrm{Fe}^{3+}$ in Cr-tourmalines (at least the $80 \%$ of the $\left.\mathrm{Fe}^{3+} / \Sigma \mathrm{Fe}_{\text {tot }}\right)$.

\section{Conclusions}

A classification scheme that disregards details of ion ordering, which typically require techniques that are uncommonly realised in the geosciences community (e.g. crystal structure refinements) is desirable. In this regard, the tourmaline ordered formula would best assist mineralogists and petrologists in identifying tourmaline species. The tourmaline nomenclature can be simplified further by merging the chemical information over the $Y$ and $Z$ sites that results in ${ }^{[6]} \mathrm{Al}-\mathrm{V}-\mathrm{Cr}-\mathrm{Fe}^{3+}$ diagrams.

This study describes the second world-occurrence of the rare vanadio-oxy-dravite from the Tzarevskoye uranium-vanadium deposit, Lake Onega, Karelia Republic, Russia, along with the first world-occurrence of chromium-dravite from the relatively close Velikaya Guba gold-copper-uranium occurrence. These provided an excellent opportunity to use the new ${ }^{[6]} \mathrm{Al}-\mathrm{V}-\mathrm{Cr}-\mathrm{Fe}^{3+}$ diagrams for the tourmaline classification. This approach has also been successfully applied to other oxy- and hydroxy-Al-tourmalines rich in $\mathrm{V}-\mathrm{Cr}-\mathrm{Fe}^{3+}$ from the literature. Results show the robust classification of tourmalines by using only the chemical data.

Supplementary material. To view supplementary material for this article, please visit https://doi.org/10.1180/mgm.2020.77

Acknowledgements. We are grateful to M. Serracino who assisted with chemical analyses. Funding by Sapienza University of Rome (Prog. Università 2018 to F. Bosi) is gratefully acknowledged. Comments and suggestions by D. Henry, A. Ertl and the Associate Editor, were much appreciated.

\section{References}

Ahmadi S., Tahmasbi Z., Khalaji A.A. and Zal F. (2019) Chemical variations and origin of tourmalines in Laleh Zar granite of Kerman (Southeast Iran). Periodico di Mineralogia, 88, 117-129. 
Andreozzi G.B., Bosi F., Celata B., Capizzi L.S., Stagno V. and BeckettBrown C.E. (2020) Crystal-chemical behaviour of $\mathrm{Fe}^{2+}$ in tourmaline dictated by structural stability: insights from a schorl with formula $\mathrm{Na}^{\mathrm{Y}}\left(\mathrm{Fe}_{2}^{2+} \mathrm{Al}\right)^{\mathrm{Z}}\left(\mathrm{Al}_{5} \mathrm{Fe}^{2+}\right)\left(\mathrm{Si}_{6} \mathrm{O}_{18}\right)\left(\mathrm{BO}_{3}\right)_{3}(\mathrm{OH})_{3}(\mathrm{OH}, \mathrm{F})$ from Seagull batholith (Yukon Territory, Canada). Physics and Chemistry of Minerals, 47, 25.

Arif M., Henry D.J. and Moon C.J. (2010) Cr-bearing tourmaline associated with emerald deposits from Swat, NW Pakistan: Genesis and its exploration significance. American Mineralogist, 95, 799-809.

Bačík P., Méres Š. and Uher P. (2011) Vanadium-bearing tourmaline in metacherts from Chvojnica, Slovak Republic: crystal chemistry and multistage evolution. The Canadian Mineralogist, 49, 195-206.

Badalov S.T. (1951) A new variety of tourmaline. Zapiski Vseseyuznogo Mineralogicheskogo Obishchestva, 2, 84-89 [in Russian].

Baksheev I.A., Prokof ev V. Yu., Yapaskurt V.O., Vigasina M.F., Zorina L.D. and Solov'ev V.N. (2011) Ferric-iron-rich tourmaline from the Darasun gold deposit, Transbaikalia, Russia. The Canadian Mineralogist, 49, 263-276.

Bassett H. (1953) A vanadiferous variety of tourmaline from Tanganyika. Records of the Geological Survey of Tanganyika, 3, 93-96.

Boitsov A.V. (1997) The mineral composition and the ore types of the uranium-vanadium deposit Srednaya Padma (Onega region, Russian Federation). Pp. 259-269 in: Changes and Events in Uranium Deposit Development, Exploration, Resources, Production and the World Supply-Demand Relationship (IAEA editor), Vienna, Austria.

Borozdin A.P., Polekhovskii Yu. S., Bushmin S.A., Glebovitskii V.A., Belyatskii B.V. and Savva E.V. (2014) Age of metasomatism and ore formation in the Srednyaya Padma vanadium precious metals uranium deposit (Karelia, Baltic Shield). Doklady Earth Sciences, 454, 68-71.

Bosi F. (2013) Bond-valence constraints around the O1 site of tourmaline. Mineralogical Magazine, 77, 343-351.

Bosi F. (2018) Tourmaline crystal chemistry. American Mineralogist, 103, 298-306

Bosi F., Lucchesi S. and Reznitskii L. (2004) Crystal chemistry of the dravitechromdravite series. European Journal of Mineralogy, 16, 345-352.

Bosi F., Reznitskii L. and Skogby H. (2012) Oxy-chromium-dravite, $\mathrm{NaCr}_{3}\left(\mathrm{Cr}_{4} \mathrm{Mg}_{2}\right)\left(\mathrm{Si}_{6} \mathrm{O}_{18}\right)\left(\mathrm{BO}_{3}\right)_{3}(\mathrm{OH})_{3} \mathrm{O}$, a new mineral species of the tourmaline supergroup. American Mineralogist, 97, 2024-2030.

Bosi F., Reznitskii L. and Sklyarov E.V. (2013a) Oxy-vanadium-dravite, $\mathrm{NaV}_{3}\left(\mathrm{~V}_{4} \mathrm{Mg}_{2}\right)\left(\mathrm{Si}_{6} \mathrm{O}_{18}\right)\left(\mathrm{BO}_{3}\right)_{3}(\mathrm{OH})_{3} \mathrm{O}$ : crystal structure and redefinition of the "vanadium-dravite" tourmaline. American Mineralogist, 98, 501-505.

Bosi F., Skogby H., Hålenius U. and Reznitskii L. (2013b) Crystallographic and spectroscopic characterization of Fe-bearing chromo-alumino-povondraite and its relations with oxy-chromium-dravite and oxy-dravite. American Mineralogist, 98, 1557-1564.

Bosi F., Skogby H., Reznitskii L. and Hålenius U. (2014a) Vanadio-oxy-dravite, $\mathrm{NaV}_{3}\left(\mathrm{Al}_{4} \mathrm{Mg}_{2}\right)\left(\mathrm{Si}_{6} \mathrm{O}_{18}\right)\left(\mathrm{BO}_{3}\right)_{3}(\mathrm{OH})_{3} \mathrm{O}$, a new mineral species of the tourmaline supergroup. American Mineralogist, 99, 218-224.

Bosi F., Reznitskii L., Skogby H. and Hålenius U. (2014b) Vanadio-oxy-chromium-dravite, $\mathrm{NaV}_{3}\left(\mathrm{Cr}_{4} \mathrm{Mg}_{2}\right)\left(\mathrm{Si}_{6} \mathrm{O}_{18}\right)\left(\mathrm{BO}_{3}\right)_{3}(\mathrm{OH})_{3} \mathrm{O}$, a new mineral species of the tourmaline supergroup. American Mineralogist, 99, 1155-1162.

Bosi F., Cámara F., Ciriotti M.E., Hålenius U., Reznitskii L. and Stagno V. (2017a) Crystal-chemical relations and classification problems in tourmalines belonging to the oxy-schorl-oxy-dravite-bosiite-povondraite series. European Journal of Mineralogy, 29, 445-455.

Bosi F., Reznitskii L., Hålenius U. and Skogby H. (2017b) Crystal chemistry of Al-V-Cr oxy-tourmalines from Sludyanka complex, Lake Baikal, Russia. European Journal of Mineralogy, 29, 457-472.

Bosi F., Biagioni C. and Oberti R. (2019a) On the chemical identification and classification of minerals. Minerals, 9, 591-602.

Bosi, F., Hatert, F., Hålenius, U., Pasero, M., Miyawaki, R. and Mills, S.J. (2019b) On the application of the IMA-CNMNC dominant-valency rule to complex mineral compositions. Mineralogical Magazine, 83, 627-632.

Cavarretta G. and Puxeddu M. (1990) Schorl-dravite-ferridravite tourmalines deposited by hydrothermal magmatic fluids during early evolution of the Larderello geothermal field, Italy. Economic Geology, 85, 1236-1251.

Cempírek J., Houzar S., Novák M., Groat L.A., Selway J.B. and Šrein V. (2013) Crystal structure and compositional evolution of vanadium-rich oxy dravite from graphite quartzite at Bítovánky, Czech Republic. Journal of Geosciences, 58, 149-162.
Cossa A. and Arzruni A. (1883) Chromturmalin aus den Chromeisenlagern des Ural. Zeitschrift für Krystallographie und Mineralogie, 7, 1-16 [in German].

Dunn P.J. (1977) Chromium in dravite. Mineralogical Magazine, 41, 408-410. Dutrow B.L. and Henry D.J. (2011) Tourmaline: A geologic DVD. Elements, 7, 301-306.

Ertl A., Rossman G.R., Hughes J.M., Ma C. and Brandstätter F. (2008) $\mathrm{V}^{3+}$-bearing, Mg-rich, strongly disordered olenite from a graphite deposit near Amstall, Lower Austria: A structural, chemical and spectroscopic investigation. Neues Jahrbuch für Mineralogie, Abhandlungen, 184, 243-253.

Ertl A., Baksheev I.A., Giester G., Lengauer C.L., Prokof ev V.Yu. and Zorina L.D. (2016) Bosiite, $\mathrm{NaFe}_{3}^{3+}\left(\mathrm{Al}_{4} \mathrm{Mg}_{2}\right)\left(\mathrm{Si}_{6} \mathrm{O}_{18}\right)\left(\mathrm{BO}_{3}\right)_{3}(\mathrm{OH})_{3} \mathrm{O}$, a new ferric member of the tourmaline supergroup from the Darasun gold deposit, Transbaikalia, Russia. European Journal of Mineralogy, 28, 581-591.

Foit F.F., Jr. and Rosenberg P.E. (1979) The structure of vanadium-bearing tourmaline and its implications regarding tourmaline solid solutions. American Mineralogist, 64, 788-798.

Gatta G.D., Bosi F., McIntyre G.J. and Skogby H. (2014) First accurate location of two proton sites in tourmaline: a single-crystal neutron diffraction study of oxy-dravite. Mineralogical Magazine, 78, 681-692.

Gorskaya M.G., Frank-Kamenetskaya O.V., Rozhdestvenskaya I.V. and Frank-Kamenetskii V.A (1984) Crystal structure of chromdravite, a new mineral. Pp. 48-49 in: Proceedings of the $27^{\text {th }}$ International Geological Congress. Moscow, Russia.

Gorskaya M.G., Frank-Kamenetskaya O.V., Rozhdestvenskaya I.V., Frank-Kamenetskii V.A., Rumyantseva E.V. and Kozlov V.S. (1987) Isomorphism of chromium-bearing tourmaline. Pp. 49-61 in: Comparative Crystal Chemistry (V.S. Urusov and D. Pushcharovsky, editors). House of Moscow State University, Moscow [in Russian].

Gorskaya M.G., Frank-Kamenetskaya O.V. and Frank-Kamenetskii V.A. (1989) Simulation the structure of tourmaline using the unit cell parameters. Pp. 119-130 in: Methods of Diffraction Studies of Crystalline Materials (V.A. Frank-Kamenetskii and B.M. Shmakin, editors). Nauka, Novosibirsk, Russia [in Russian].

Grice J.D. and Ercit T.S. (1993) Ordering of Fe and Mg in the tourmaline crystal structure: the correct formula. Neues Jahrbuch für Mineralogie, Abhandlungen, 165, 245-266.

Grice J.D., Ercit T.S. and Hawthorne F.C. (1993) Povondraite, a redefinition of the tourmaline ferridravite. American Mineralogist, 78, 433-436.

Hammarstrom J.M. (1989) Mineral chemistry of emeralds and some associated minerals from Pakistan and Afghanistan: an electron microprobe study. Pp. 125-150 in: Emeralds of Pakistan: Geology, Gemology and Genesis (A.H. Kazmi and L.W. Snee, editors). Geological Survey of Pakistan and Van Nostrand Reinhold Co., New York.

Henry D.J. and Dutrow B.L. (2018) Tourmaline studies through time: contributions to scientific advancements. Journal of Geosciences, 63, 77-98.

Henry D.J., Novák M., Hawthorne F.C., Ertl A., Dutrow B., Uher P. and Pezzotta F. (2011) Nomenclature of the tourmaline supergroup minerals. American Mineralogist, 96, 895-913.

Henry D.J., Novák M., Hawthorne F.C., Ertl A., Dutrow B., Uher P. and Pezzotta F. (2013) Erratum. American Mineralogist, 98, 524.

Jan M.Q., Kempe D.R.C. and Symes R.F. (1972) A chromian tourmaline from Swat, West Pakistan. Mineralogical Magazine, 38, 756-759.

Kazachenko V.T., Butsik L.A., Sapin V.I., Kitaev I.V., Barinov N.N. and Narnov G.A. (1993) Vanadian-chromian tourmaline and vanadian muscovite in contact-metamorphosed carbonaceous rock, Primorye, Russia. The Canadian Mineralogist, 31, 347-356.

Lupulescu M. and Rowe R. (2011) Al-rich chromium-dravite from \#1 mine, Balmat, St. Lawrence Country, New York. The Canadian Mineralogist, 49, 1189-1198.

Nuber B. and Schmetzer K. (1979) Die Gitterposition des $\mathrm{Cr}^{+3}$ im Turmalin: Strukturverfeinerung eines Cr-reichen Mg-Al-Turmalin. Neues Jahrbuch für Mineralogie, Abhandlungen, 137, 184-197 [in German].

Peltola E., Vuorelainen Y. and Hakli T.A. (1968) A chromian tourmaline from Outokumpu, Finland. Bulletin of the Geological Society of Finland, 40, 35-38. 
Pesquera A., Gil-Crespo P.P,Torres-Ruiz F., Torres-Ruiz J. and Roda-Robles E. (2016) A multiple regression method for estimating Li in tourmaline from electron microprobe analyses. Mineralogical Magazine, 80, 1129-1133.

Pouchou J.L. and Pichoir F. (1991) Quantitative analysis of homogeneous or stratified microvolumes applying the model "PAP". Pp. 31-75 in: Electron Probe Quantitation (K.F.J. Heinrich and D.E. Newbury, editors). Plenum, New York.

Reznitskii L.Z. and Sklyarov E.V. (1996) Unique Cr-V mineral association in metacarbonate rocks of the Sludyanka, Russia. P. 446 in: Proceedings $30^{\text {th }}$ International Geological Congress, Beijing, China.

Reznitskii L.Z., Sklyarov E.V. and Ushapovskaya Z.F. (1988) Minerals of chromium and vanadium in Sludyanka crystalline complex (southern Pribaikalia). Pp. 64-74 in: Metamorphic formations of Pre-Cambrian of Eastern Siberia (V.G. Belichenko, editor). Nauka, Novosibirsk, Russia.

Reznitskii L., Clark C.M., Hawthorne F.C., Grice J.D., Skogby H., Hålenius U. and Bosi F. (2014) Chromo-alumino-povondraite, $\mathrm{NaCr}_{3}\left(\mathrm{Al}_{4} \mathrm{Mg}_{2}\right)\left(\mathrm{Si}_{6} \mathrm{O}_{18}\right)$ $\left(\mathrm{BO}_{3}\right)_{3}(\mathrm{OH})_{3} \mathrm{O}$, a new mineral species of the tourmaline supergroup. American Mineralogist, 99, 1767-1773.

Rozhdestvenskaya I.V., Vereshchagin O.S., Frank-Kamenetskaya O.V., Zolotarev A.A. and Pekov I.V. (2011) About crystallochemical formula of chromdravite - mineral species of tourmaline. Proceedings of the Russian Mineralogical Society, 3, 93-99.

Rumyantseva E.V. (1983) Chromdravite, a new mineral from Karelia. Proceedings of the Russian Mineralogical Society, 112, 222-225.

Sheldrick G.M. (2013) SHELXL2013. University of Göttingen, Germany.

Sipahi F. (2019) Nature of tourmaline formation in quartz porphyry in the E Sakarya zone (NE Turkey): Geochemistry and isotopic approach. Periodico di Mineralogia, 88, 333-351.

Snetsinger G.K. (1966) Barium-vanadium muscovite and vanadium tourmaline from Mariposa County, California. American Mineralogist, 51, 1623-1639.

van Hinsberg V.J., Henry D.J. and Dutrow B.L. (2011) Tourmaline as a petrologic forensic mineral: A unique recorder of its geologic past. Elements, 7, 327-332.

Vereshchagin O.S., Rozhdestvenskaya I.V., Frank-Kamenetskaya O.V. and Zolotarev A.A. (2014) Ion substitutions and structural adjustment in Cr-bearing tourmalines. European Journal of Mineralogy, 26, 309-321.

Żàĉek V., Frýda J., Petrov A. and Hyršl J. (2000) Tourmalines of the povondraite-(oxy)dravite series from the cap rock of meta-evaporite in Alto Chapare, Cochabamba, Bolivia. Journal of the Czech Geological Society, 45, 1-2. 